\title{
An Educational Strategy to Inform Legislators and Nurses About the Professional Nursing Role
}

Judith Young

Department of Community and Health Systems, Indiana University School of Nursing, Indianapolis, Indiana.

\begin{abstract}
Nurses provide an informed perspective to influence decision making with health carerelated legislation. This article describes a strategy that can inform legislators about the contemporary nursing role and its influence on patient safety, as well as raise nurse awareness of the professional responsibility for political advocacy and how to engage in this role.
\end{abstract}

This is the author's manuscript of the article published in final edited form as:

Young, J. (2019). An Educational Strategy to Inform Legislators and Nurses About the Professional Nursing Role. The Journal of Continuing Education in Nursing, 50(4), 150-152. https://doi.org/10.3928/00220124-20190319-04 
Political advocacy is an increasingly significant competency of the professional nursing role due to the expectation that nurses deliver high-quality care, evaluate care outcomes, and provide leadership to integrate evidence into practice in order to improve care. The revised nursing Code of Ethics clearly states that the nurse must advocate for and protect patient rights and safety and advance nursing and health policies founded upon evidence (Fowler, 2015). Political advocacy may represent a theory-practice gap for nurses who graduated prior to the revision of the code of ethics. Whereas the prior role as patient advocate focused on advocacy at the point of care, the current role is to advocate at the legislative and policy level as well. The political advocacy role is important due to the fact that nurses are strategically situated to witness the influence of health legislation upon patient care delivery. Current events such as health care reform, declining reimbursements, and the focus on efficiency and quality outcomes demonstrate the importance of the nurse's informed voice (Primomo \& Björling, 2013).

Despite the professional expectation, and the fact that legislation directly influences nursing research, education, and practice, nurses remain hesitant to embrace political advocacy as a professional responsibility. The influence of the nursing profession upon health policy has been limited as a result. It is essential that nurses become political advocates to influence the decision making of legislators at the state and federal levels. However, to act as political advocates, nurses must be prepared with the basic knowledge. This article describes a strategy that nursing professional development educators can use to inform local, state, or federal legislators about the contemporary nursing role and its influence on patient safety and health care delivery. Additionally, this strategy can also raise nurse awareness of the professional responsibility for political advocacy and how to engage in this role.

\section{THE STRATEGY}

This educational strategy was developed as the result of a nurse's experience attending a meeting of the Health Care Committee members at the statehouse. During the meeting, an influential legislator in an effort to promote political advocacy remarked that it is important to be informed of the legislative process and bills being considered, due to the fact that legislators make decisions that impact health care delivery and nursing practice 
frequently. This statement resonated with the nurse because it made clear that decisions were being made by policy makers who likely were un-informed about the contemporary role of the nurse professional and the current challenges associated with patient care delivery. Also, that political advocacy by a nurse professional was essential in order to facilitate informed decision making by legislators. At the end of the session, the nurse extended an invitation to the legislator to visit the health care organization to witness the contemporary role of the nursing professional. The legislator accepted the invitation and the process that ensued to prepare for the visit, and the day's agenda is described here.

The first step in the process was to meet with the Chief Nurse Officer (CNO) to attain official permission for the visit. The CNO promptly assembled a taskforce, which included herself, the Community Relations Officer, the nurse who extended the invitation, and a Clinical Director. At the first meeting, each member assumed specific duties. For example, the nurse who extended the invitation conducted a literature review to determine which components of the nurse's role to highlight. The nurse also consulted with the Director of the State Nursing Association for political insight and established herself as the primary contact with the legislator's office. The Community Relations Director was responsible for the details associated with advertising and publicity. The CNO consulted the corporate legal department and issued an official invitation on behalf of the organization. The Clinical Director identified the nurses, managers, and unit locations for the visit.

Guided by the literature review, the taskforce identified key components of a nurse's role that were being influenced by pending legislation. Although each clinical agency would choose relevant aspects of the role as it pertains to pending legislation at its site, one component identified by this taskforce was the use of technology (Macias, BernabeuAndreu, Arribas, Navarro, \& Baldominos, 2018). Time would be allotted for the legislator to witness the use of technology by nurses with patient care management. The second component identified was to showcase the nurse's role on the interprofessional team during patient care rounds when nurses report to various disciplines, including physicians, pharmacists, dieticians, chaplains, and social workers. The third component was to highlight nursing certification and its effects on patient quality outcomes. The taskforce 
also decided to develop an online educational module focused on political advocacy and the professional nursing role. Module topics would include a definition of health policy; clarification of the process for a bill to become a law; directions to locate state and federal representatives, as well as the current issues being presented at the state and federal levels; strategies to influence policy making; and a listing of resources to support political advocacy including the advocacy role of professional nursing organizations. A case study focused on a current "legislative topic," such as a pending House Bill would be the active learning strategy used to synthesize the module content. This online module would be completed by those involved prior to the legislator's visit.

\section{THE AGENDA}

The next step was to develop the visit agenda. At the start of the visit, the nurse who had extended the initial invitation greeted the legislator in the front lobby and accompanied her to the CNO's office to meet the task-force members. At this time, photographs were taken and the taskforce reviewed the agenda and goals with the legislator (Table 1).

\section{OUTCOMES}

There were two tangible outcomes from the legislator's visit. First, the legislator, much to the surprise of those attending the final debriefing meeting, reported that she had never been invited to witness the contemporary role of the nurse at the bedside-only to meet with executive leadership. The legislator acknowledged that the visit was informative and that the nurse at point of care was indeed the expert related to patient care delivery. The legislator also discussed pending legislation with the nurses present and solicited their opinions.

Due to the publicity generated by the legislator's visit, the second outcome was a feature article in the local paper focused on the technology that supports professional nursing practice and patient care management.

\section{CONCLUSIONS AND IMPLICATIONS FOR NURSING PRACTICE}

Nurses are strategically positioned to provide the informed perspective to influence the decision making by legislators related to nursing practice, education, and health care 
delivery. Inviting the legislator to witness the contemporary role of the nurse in the clinical setting raised awareness of the need for nurses to act as political advocates in the legislative arena. The event made clear to those involved that unless the nurse assumes the advocacy role, patient safety is at risk. Although this event was structured for a legislator's visit at one particular health care organization, professional development educators can replicate this event to not only educate legislators about contemporary nursing practice but also to encourage nurses to embrace their professional responsibility to engage in political advocacy. 


\section{TABLE 1}

\section{AGENDA FOR THE VISIT: 8:30 A.M. TO 12:30 P.M.}

\begin{tabular}{|c|c|c|}
\hline Time & Activity and Staff Involved & Goals \\
\hline Pre-visit & $\begin{array}{l}\text { Development of the Political } \\
\text { Advocacy online module }\end{array}$ & $\begin{array}{l}\text { Completion of the Educational Module by nurses who } \\
\text { would be involved in the visit }\end{array}$ \\
\hline $\begin{array}{l}8: 30 \text { to } \\
9: 15 \text { a.m. }\end{array}$ & $\begin{array}{l}\text { Nurse meets the legislator in } \\
\text { the lobby and escorts her to } \\
\text { the Chief Nurse Officer's } \\
\text { office to meet the taskforce }\end{array}$ & $\begin{array}{l}\text { Meet and greet with the legislator and taskforce } \\
\text { members } \\
\text { Review the 4-hour agenda } \\
\text { Photograph opportunity }\end{array}$ \\
\hline $\begin{array}{l}9: 30 \text { to } \\
10: 00 \\
\text { a.m. }\end{array}$ & $\begin{array}{l}\text { Nursing rounds in the } \\
\text { intensive care unit } \\
\text { Nurse and legislator }\end{array}$ & $\begin{array}{l}\text { Witness the nurses' role on the interdisciplinary team } \\
\text { Observe the communication, respectful collaboration, } \\
\text { expertise, and contribution of each discipline to } \\
\text { patient care }\end{array}$ \\
\hline $\begin{array}{l}10: 00 \text { to } \\
11: 00 \\
\text { a.m. }\end{array}$ & $\begin{array}{l}\text { Tour the unit to view the } \\
\text { technology used with patient } \\
\text { care management in the } \\
\text { intensive care unit } \\
\text { Nurse and legislator }\end{array}$ & $\begin{array}{l}\text { Nurses demonstrated competencies required with } \\
\text { technology and informatics: } \\
\text { Electronic medical record with communication and } \\
\text { charting } \\
\text { Bar code medication administration } \\
\text { Smart pump technology for drug administration } \\
\text { Care of the patient on a ventilator } \\
\text { Intracerebral monitoring } \\
\text { Continuous renal replacement therapy } \\
\text { Hypothermia therapy postcardiac arrest } \\
\text { Patient classification system }\end{array}$ \\
\hline
\end{tabular}




\begin{tabular}{|c|c|c|}
\hline Time & Activity and Staff Involved & Goals \\
\hline $\begin{array}{l}11: 00 \\
11: 30 \\
\text { a.m. }\end{array}$ & $\begin{array}{l}\text { Tour the oncology unit } \\
\text { Nurse clinician, nurse } \\
\text { manager, and legislator }\end{array}$ & $\begin{array}{l}\text { Legislator observed the charge nurse role. } \\
\text { Nurses outlined the competencies required to be an } \\
\text { oncology certified nurse, including the administration } \\
\text { of chemotherapy agents, maintenance of access } \\
\text { devices, and the protective inter-ventions to care for } \\
\text { the immune-compromised patient. } \\
\text { Nurses clarified that a specialty certification } \\
\text { exemplified a nurse's commitment to patient safety } \\
\text { through lifelong learning and self-regulation. }\end{array}$ \\
\hline $\begin{array}{l}11: 30 \\
\text { a.m. to } \\
12: 30 \\
\text { p.m. }\end{array}$ & $\begin{array}{l}\text { Meet and greet nurses at } \\
\text { different levels of the clinical } \\
\text { nurse ladder } \\
\text { Nurse, Clinical Director, Chief } \\
\text { Nurse Officer, and legislator }\end{array}$ & $\begin{array}{l}\text { Nurses outlined the levels of the clinical ladder and } \\
\text { explained why they felt it was important to pursue } \\
\text { advancement from a professional and personal } \\
\text { perspective. } \\
\text { Debriefing } \\
\text { The legislator spoke about the importance of political } \\
\text { advocacy and establishing relationships with } \\
\text { legislators } \\
\text { The legislator outlined a health-related pending bill } \\
\text { being considered and solicited feedback from the } \\
\text { nurses present related to their informed opinion. } \\
\text { Photograph opportunity }\end{array}$ \\
\hline $\begin{array}{l}12: 30 \\
\text { p.m. }\end{array}$ & $\begin{array}{l}\text { Nurse accompanies the } \\
\text { legislator to the front lobby }\end{array}$ & $\begin{array}{l}\text { Thank the legislator and summarize key points about } \\
\text { the visit linked to pending legislation. }\end{array}$ \\
\hline Follow-up & $\begin{array}{l}\text { Chief Nurse Officer sends an } \\
\text { official thank you }\end{array}$ & $\begin{array}{l}\text { Continue to follow up with pending legislation with } \\
\text { nurses involved in the visit encouraging them to } \\
\text { communicate with legislators in their own districts }\end{array}$ \\
\hline
\end{tabular}




\begin{tabular}{|c|c|c|}
\hline Time & Activity and Staff Involved & Goals \\
\hline & & $\begin{array}{l}\text { about each bill that affects nurses, nursing care, and } \\
\text { patients' needs. }\end{array}$ \\
\hline
\end{tabular}




\section{REFERENCES}

1. Fowler M. (2015). Guide to the Code of Ethics for Nurses With Interpretive Statements(2nd ed.). Silver Spring, MD:American Nurses Association.

2. Macias M., Bernabeu-Andreu F.A., Arribas I., Navarro F., Baldominos G. (2018). Impact ofabar code medication administration system on patient safety. Oncology Nursing Forum, 45, E1-E13. 10.1188/18.ONF.E1-E13

3. Primomo J., Björling E.A. (2013). Changes in political astuteness following nurse legislative day. Policy, Politics, \& Nursing Practice, 14(2), 97-108. $10.1177 / 1527154413485901$ 